\title{
Whale Watching as Ecotourism: How Sustainable is it?
}

\author{
Stephen L. Wearing \\ University of Technology, Sydney \\ Paul A. Cunningham \\ Rikkyo University, Tokyo \\ Stephen Schweinsberg \\ University of Technology, Sydney \\ Chantelle Jobberns \\ University of Technology, Sydney
}

\begin{abstract}
Whale Watching as an alternative to the practice of commercial and 'scientific' whaling has evolved as an ecotourism activity. This paper explores whale watching in an effort to determine its economic and social viability as a sustainable, marine tourism activity - and whether the whale and the tourist can coexist in the future. We define whale watching as an ecotourism product, as it holds the potential for sustainable practice, one that is both ecologically sound and profitable. Responsible whale watching is seen as a clean, green industry that simultaneously supports local economies and promotes whale education and conservation. The question is, can this ecotourism activity live up to these expectations?
\end{abstract}

\section{Introduction}

In 2001, the Journal of Sustainable Tourism published an article looking at the transition from whale hunting in Tonga to whale watching (Orams, 2001).Since then, the overnight growth of the whale watching industry has 'industrialised the ocean' (Corkeron 2004, p. 848).Viewed by the International Whaling Commission (IWC) in 1983 as an alternative 'use' for whales, today whale watching is recognised as a legitimate form of ecotourism (Orams, 2000), although viewed by some as 'an acceptable form of benign exploitation (Gillespie 2003, p. 408).Leading up to 2001, the international whale watching industry was valued at over \$1 billion USD (Hoyt 2001), and attracted oven 9 million people annually.According to the International Fund for Animal Welfare (IFAW), by 2008 this number had grown to over 13 million people, participating in over 119 countries (O’Connor et. al, 2009). 
Patrick Ramage, the Director of the IFAW whale program, notes that whale watching revenues have more than doubled since 1998, and that whale-watching operations around the world now include 3,330 operators and employ an estimated 13,200 people with the fastest growth seen in Asia (O’Connor et al. 2009). Peter Garrett, the former Australian Environment Minister, reports that the whale watching industry generated \$2.1 billion USD of tourism revenue worldwide (AFP 2009). Ramage adds, 'While governments continue to debate the future of whaling, the bottom line is increasingly clear: Responsible whale watching is the most sustainable, environmentally-friendly and economically beneficial 'use ' of whales in the 21st century' (O’Connor et al. 2009, p. 9).

Whale watching guidelines suggest it can be operated within the boundaries of sustainable practice. However, with its growth worldwide; 'the whale watching industry has grown at an average rate of 3.7\% per year, comparing well against global tourism growth of $4.2 \%$ per year over the same period' (O’Connor et. al, 2009, p. 23), it may not be possible to ensure that all stakeholders operate within the parameters of sustainable practice for whale watching. At a regional level, average annual growth has exceeded tourism growth rates in five of the seven regions in this report: Asia (17\% per year), Central America and the Caribbean (13\% per year), South America (10\% per year), Oceania and the Pacific Islands (10\% per year) and Europe (7\%) (O’Connor et al. 2009, p. 23).

Currently it is logical to pursue whale watching as it is viewed positively by tourists. For example, in 2007 tourists in the Dominican Republic were surveyed to determine whether the stance of a country towards whale conservation or whaling would affect their decision about whether to visit that country on holiday. The majority (77.1\%) reported that if a Caribbean country supported the hunting or capture of whales or dolphins that they would be less likely to visit it. An even larger majority (81.1\%) stated that if a country had a strong commitment to whale and dolphin conservation, they would be more likely to visit that country on vacation (Parsons \& Draheim 2009). Additionally, it is within the interests of the whalewatching industry to ensure that it remains within sustainable practices aligned to ecotourism. Higham and Lusseaunote the need for sustainability, lest one find themselves 'slaughtering the goose that lays the golden egg' (2008, p. 63). Further empirical research is called for in order to investigate the values and views of tourists on the issue of whale watching and the wider range of animal welfare issues. 
It is believed (Wearing, Buchmann\&Jobberns 2011) that this industry evolved more quickly based, in part, on the film Free Willy, which portrayed a lone, captive orca released into the wild and reunited with his family. The star of the film was a killer whale named Keiko, who played a fundamental role in changing perceptions of killer whales from beasts that 'were feared and hunted' (as in Moby Dick) in the 1970s, to creatures that were revered and glorified following the release of the first Free Willy film (Lawrence \& Phillips 2004, p. 9) and its sequels. Considering our collective history of hunting whales, the 'save the whales' movement represented a global change in public perceptions, which humanised these animals, forcing the public to reconsider the ethics of hunting whales (Lawrence \& Phillips 2004) and to explore activities such as whale watching instead.

We argue that whale watching, as an activity, encourages people to appreciate and protect whales through their interaction and experience with these creatures. Encounters with wildlife create a need within people to help protect them (Lien 2001), and has the potential to benefit conservation from the long-term effect of changing attitudes towards wild animals and natural habitats (Duffus\&Dearden1993). Whale watching also provides the opportunity to educate people about other environmental issues affecting oceans and waterways - such as high toxin levels and pollution, and can act as a platform from which commercial tour operators can educate their tourists about long-term sustainable benefits of whale watching.

It is with this in mind that we argue that ecotourism creates a market value for the observation of animals through the commodification of wildlife and its habitats. At the same time, it provides education through direct experience and kindles a value for the natural environment. However, some have criticised the commodification and consumption of animals through whaling and whale watching on ethical grounds (Scarpaci, Parsons, \& Lück 2008). Ecotourism provides us with an opportunity to provide both conservation and commercialisation, where the direct human 'gaze' of wildlife is central to the experience (Ryan \&Saward, 2004, p. 246). Given its alignment to alternative tourism (Wearing \& Neil 2009), it is believed that ecotourism provides a mechanism to improve animal welfare and to conserve nature in general.

For the purpose of discussion, we categorise whale watching as an ecotourism activity, but acknowledge that it could fall under the umbrella of various types of tourism. Positioned as 
an ecotourism activity, we are able to examine whale watching in terms of its ability to provide strong environmental protection objectives that may also lead to a positive imagery in terms of animal welfare, thus having the potential to attract more whale-watching tourists (Kuo et al. 2009, p. 6).

The question we seek to investigate in this paper is to what degree can we consider whale watching an ecotourism activity and to what extent emerging whale-watching practices will impact beyond the parameters acceptable to ecotourism and sustainable practice. This paper presents the opportunity to explore these ideas in more detail through an analysis of the literature.

\section{Ecotourism Sustainable Growth for a Common Future}

This section investigates what ecotourism is and how whale watching fits into its remit as an extension of the sustainability discourse and as a model of tourism development that embraces the preservation of ecology and culture.According to the Japan Ecotourism Society (JES, 2010), ecotourism should utilise unique local natural, historical and cultural resources; promote the conservation and preservation of local resources through appropriate management; and should activate local communities through responsible tourism and economic development that makes sustainable use of the natural and social resources.Ecotourism Australia (EA 2010) defines ecotourism as ecologically sustainable tourism with a primary focus on experiencing natural areas that fosters environmental and cultural understanding, appreciation and conservation.

Whale watching falls within the realm of ecotourism.It focuses on the aesthetic consumption of whales through the process of a largely visual experience that is supposed to be educative in nature.Some types of whale watching are more tactile, notably the programs that offer the chance to swim with dolphins. Whether viewing whales from a promontory point on land or from the bow of a boat, this activity fosters use and appreciation of these creatures that is sustainable in nature.While 'swim with dolphin' programs have been criticised for being more akin to adventure tourism, the participants generally have a great love for these creatures. Outright categorisation of these activities is difficult, so we provide some discussion to enable judgment as to how whale watching might be postioned and how, if 
given the ecotourism banner, it might be able to standardise guidelines in a way that made it more sustainable.

Wearing and Neil (2009) suggest that the ecotourist is concerned with development and fulfilment, including self-education.This has led to an increase in the number of nature-based activities and interpretive programs in marine-based ecotourism (Zeppel \& Muloin 2008).Tisdell\& Wilson (2005) have identified the importance of learning and the interaction of tourists with wildlife as contributors to their pro-conservation sentiments and actions. With the growing presence of ecotourism and the activity of whale watching,we see an opportunity for sustainable growth.Furthermore, as a way forward,pursuing the visual consumption of whales may help the culturally sensitive issues associated with the practice of whaling to evolve by aligning use, sustainability and profit.

Ecotourism experienced a growth in popularity during the 1980s, leading up to the International Year of Ecotourism occurring in 2002.It was believed that tourists had begun to question tourism products, and were willing to pay more for tourism products that were perceived to be ethical (Boo 1990; Wight 1993; King \& Stewart 1996; Cole 2007).Wight found that ecotourists are willing to spend ' $8.5 \%$ more for services and products provided by environmentally responsible suppliers’ (1994, p. 41). Yet such findings remain contested.Cunningham found that only one out of four lodgers was willing to pay an additional $10 \sim 20 \%$ to stay at an ecolodge, even though nearly $60 \%$ of the same respondents indicated the desire to stay at one (2007, p. 31).Similarly, Kirk (1996) found that $71 \%$ of the respondents he surveyed claimed that they would prefer to stay at hotels that showed concern for the environment, but were not willing to pay extra for it.Hobson and Essex reported that few guests showed any regard for environmental practices carried out by hotels and usually only require a ‘clean, comfortable bed' with a 'good breakfast' (2001, p. 145).

In their research of ecotourist activities in Kaikoura, New Zealand, Cloke and Perkins examined the nonhuman agency of nature and the role it plays in the performance and meaning of place.The recent boom in ecotourism at this location has been 'co-constituted by the networked agency of whales and dolphins, whose charismatic animal appeal is a magnet for tourists' (2005, p. 903) and plays a role in the mediation of the meaning of place.This research poses significant questions about the ability of actor networks and relational 
networks to fully capture the power of nonhumans to evoke 'sublime emotional and aesthetic relations with humans' (2005, p. 903).

Hoyt notes the importance of ecotourism and other organisational structures to ensure the validity of whale watching as an ecotourist activity.Noting that the Atlantic islands comprise nearly a third of all marine protected areas (MPAs) worldwide, the author reports that few of these MPAs have management plans that include strategies for sustainable ecotourism. When whale watching is conducted in a sustainable manner, especially in or near a cetacean MPA, and with other regulations in place, it has the capacity to take a leading role in the development of an island-based ecotourism industry (2005, p. 141).

Whale and dolphin watching has now become the fastest growing sector of the eco-tourism industry (Corkeron 2004; Curtin 2003).Although whale watching is part of the global tourism trade, it is really a community level industry. Whale watching tourists support local economies through their purchases, from whale watching tickets to associated expenses for travel, food, hotels and souvenirs.Beyond economics, the whale watching industry offers communities a sense of identity and cultural pride, and helps foster an appreciation for the marine environment.This supports local businesses, creating jobs and providing income (IFAW 2010).

There are many advantages of this kind of ecotourism.If conducted properly this activity is relatively benign (Blewitt 2008; Jensen et al. 2009; Lusseau, Bain, Williams \& Smith 2009; Noren, Johnson, Rehder \& Larson 2009).Through proper management, whale watching has proven to be profitable and sustainable.This approach provides a resource for ongoing cetacean research as well as a context in which to promote an appreciation of the marine environment and to explore conservation issues in the public discourse (Greenpeace 2010).

Whale watching has widely been viewed as a harmless activity with considerable educational and conservation benefits. However, there is growing concern about the inadvertent damage caused by whale watching. The questions scientists, policy makers and the tourism industry are facing are how to determine the conditions under which whale watching becomes detrimental to the animals it targets, and how to best protect them (Simmonds et al. 2007).Higham and Lusseau $(2007,2008)$ have echoed the urgent need for empirical research into whale watching. 
Parsons, Lück and Lewandowski (2006) and Scarpaci, Parsons, and Lück(2008) note that whale-watching research encompasses a wide variety of disciplines and fields of study, includes 'monitoring the biological impacts of whale-watching activities on cetaceans and assessments of the effectiveness of whale-watching management and regulations, to the sociological and economic aspects of whale watching on communities hosting such activities' (2008, p. 55).The conflicting use of marine mammals as non-consumptive versus consumptive is attracting more attention.

In order to ensure the viability of whale watching in the future under the ecotourism banner, one needs to examine the educative elements of this activity and the social impact it has upon the participants.While whale watching is widely assumed to enhance people's awareness and appreciation of whales - and perhaps lead to a greater sense of conservation and protection of the environment - one needs to evaluate the educational impact of this activity.In their examination of whale watching experiences in New South Wales, Australia, Stamation et al. found that 'the current education provided lacks structure, there are no clear conservation objectives, and there is limited addition to knowledge and conservation behaviors of whale watchers in the long term' (2007, p. 41).

In order to justify this ecotourism activity and to validate its claims of inspiring conservation and environmental awareness, the whale watching industry needs to address these issues.In his investigation of dolphin-swim tours in New Zealand, Lück found a demand for structured interpretation programs on marine mammal tours, with respondents clearly indicating that they would have liked to receive more information, in particular about the wider marine environment (2003, p. 943).

Zeppel and Muloin (2007) echo the call for further research examining the educational component of marine wildlife tourism in order to be able to assess whether or not there is an increase in tourist knowledge and whether there are any attitudinal shifts or lifestyle changes that help to conserve marine wildlife.In a meta-analysis of guided tourist encounters with whales, dolphins and marine turtles from 1996 to 2007, the authors conclude that mediated encounters with marine wildlife contribute to pro-environmental attitudes and improved onsite behavior, with some longer-term intentions to engage in conservation actions that benefit marine species. 
In order to effectively manage wildlife tourism, the biological impacts as well as the needs of tourists, industry and other stakeholders need to be taken into consideration.Stamation (2008) suggests that an adaptive management system that is both integrative and holistic be adopted in the management of whale watching. This would allow for the study of both the human and animal dimensions of this activity by incorporating biological and social sciences.Such an approach would provide a framework for maximising the benefits of whale-watching, while at the same time minimising the adverse effects on whales.

\section{Sustainable Practices}

With the current trend towards animal and environmental awareness, people have become eager to experience wildlife and nature (Amante-Helweg, 1996). Over the last 20 years there has been an awakening interest and a general fascination in observing cetaceans (i.e. whales, dolphins and porpoises) in their natural environment (Orams 2000; Muloin 1998; Neil \&Breize 1998; Corkeron 2004; Curtin 2003). Data available for Australia reveal that in 1994 approximately 600,000 people participated in whale watching activities. It was also estimated that over \$4.5 million USD was generated directly from whale watching tours for the year 1994 (Anderson et al. 1996; Hoyt 1996). Currently, whale watching in Australia generates an estimated \$100 million USD a year. Four times as many whale watching locations exist in 2010 than existed in 2005 in Australia (Whale and Dolphin Watch Australia, 2010).

In popular whale watching destinations like Hervey Bay, Australia, whale watching activities create significant economic, social and educational benefits for the region (Foxlee 2001). However, whale watching is not without its own impacts, which we explore here to provide insights into the difficulties in considering it a bonifide ecotourism activity that consistently operates according to sustainable practices. Marine tourism often targets specific cetacean communities that are repeatedly sought out for prolonged, close-up encounters (especially in the case of dolphin swim programs). As the demand for more frequent and intimate encounters increases, so does the responsibility of conservation authorities and the scientific community to assess the effects of these activities upon the animals (Corkeron 2006).

The IFAW's scientific work related to whale watching has aimed at facilitating data collection relevant to general whale conservation, and studying the effects of whale watching 
on whales. The focus has been on developing benign, non-intrusive techniques that can be used from whale watching vessels (O’Connor et. al. 2009, p. 12). Software developed by the IFAW for data collection is now used around the world by whale watching operations and other researchers. The IFAW has also contributed to studies concerned with compliance, regulations and guidelines (Wiley et al., 2004), their scientific basis and techniques for monitoring these more effectively (DeNardo et al. 2001; Leaper \& Gordon 2001).

Human interaction with cetaceans can cause short-term changes in the behaviour of these creatures, such as alterations to foraging strategies or reduced maternal care, which in the long term can lead to the displacement from preferred habitats or reduced reproductive success (Blewitt 2008). For this reason, a variety of strategies have been implemented in an effort to manage and control whale-watching activities throughout Australia and other whale watching locations. These strategies include regulations, permit and licensing systems, industry guidelines, education, and interpretation. An important component supporting these management systems is research.

A growing number of studies have investigated the impact of vessel noise on cetacean communication. Jensen et al. (2009) suggest that the increasing number and speed of vessels may have reduced the habitat quality of cetaceans by increasing the underwater noise level. Lusseau, Bain et al. (2009) report that vessel traffic has disrupted the foraging behavior of southern killer whales (Orcinus orca), resident around San Juan Island, Washington, USA. Noren et al. (2009) focused on the same group of whales, reporting that the surface-active behaviors (SABs) of these whales were affected by the proximity of vessels in the area. The authors conclude that the minimum approach distance of 100 meters in whale watching guidelines may be insufficient in preventing behavioral responses from whales.

Weinrich and Corbellistudied the potential impacts of vessel exposure on the calving rate of humpback whales off the coast of southern New England (USA), but found no direct evidence for negative effects. They posit that any 'short-term disturbance may not necessarily be indicative of more meaningful effects on either individuals or populations' (2009, p. 2931). Sousa-Lima and Clark (2008, p. 174) found an important negative effect of boat traffic on singing activity. Adaptive management should aim at reducing the number of noise events per boat, which can improve the whale watching experience and reduce the impact on male 
singing behavior.Stamation et al. (2010) found that calf pods were more sensitive to the presence of vessels than non-calf pods, and that dive times and the overall percentage of time whales spent submerged were higher in the presence of vessels. The authors caution that since the long-term impacts of the effects of vessels are unknown, management of the humpback whale-watching industry should adopt a conservative approach.

Whales and dolphins are increasingly the focus of tourism activities in many coastal locations; however the impacts of these activities remain largely unknown. In his investigation of bottlenose dolphins living in similar fjords but exposed to different levels of tourism activities, Lusseau (2004) compared the impacts of boat interactions upon these cetaceans. In particular, the author examined short-term avoidance strategies and the threshold at which those strategies were no longer effective. According to Lusseau, the resting state was the most sensitive to interactions, whereas socialising was less sensitive. Short-term displacement or in extreme cases area avoidance were typical responses to boat exposure, yet the author contends that the overall behavior of the dolphins remained largely unchanged. Short-term boat avoidance of less than 68 minutes was found to be ineffective.

The call for the monitoring and management of whale watching extends to the frigid waters of the Antarctic. Shipboard visitors are routinely rewarded with whale sightings. However, careful management and dedicated research are needed to ensure that the growing Antarctic marine tourism industry does not inadvertently harm these populations. Responsible tourism has a substantial contribution to make to Antarctic whale conservation and research through collaboration (Williams \&Crosbie, 2007, p. 195).

A review of the whale watching research (Corkeron 1996; (Scarpaci et al. 2008) revealed that so far, most studies have concentrated on the biological and behavioural aspects of whales, with little recognition given to the social aspects. This is hardly surprising, as most research concerning human-wildlife interactions has come from the biological sciences (Muloi 1998). Duffus and Dearden (1993) were among the first researchers to investigate the 'human' dimensions of whale watching in the context of managing human interaction with these creatures. They stress that both human and ecological dimensions of whale watching must be understood and balanced at all stages of management. Recent research has explored the activity of whale watching in terms of human-animal interaction and the impact on whales (Noren et al. 2009; Tosi\& Ferreira 2009; Vieira \&Brito 2009; Weinrich\&Corbelli 2009; 
Williams et al. 2009), on the income of fishing communities (Einarsson 2009), and on how to manage whale watching (Stamation 2008).

Learning more about wildlife users (e.g. whale watchers) in terms of their motivations, expectations and satisfaction would allow for more effective management strategies (Stamation, 2008). In particular, a better understanding of the 'human dimension' of whale watching would guide educational and interpretive programs aimed at whale watching participants (Orams 1999; Amante-Helweg 1996; (Stamation, Croft, Shaughnessy, Waples, \& Briggs 2007).

A few studies have specifically examined factors relating to visitor satisfaction with cetacean watching (mainly involving whales). In an Australian study, Foxlee (2001) found that the factors contributing to visitor satisfaction, in order of importance were: numbers of whales seen, distance from whales, whale activity, information about whales, information available about other marine life and style in which the information was presented.

Exploring touristic interaction with dwarf minke whales in the Great Barrier Reef, Valentine et al. found that most of the participants had low expectations about whale encounters, with only one out of four coming specifically to swim with the whales and with nearly half of the participants being content to learn about the whales on board the vessel (2004, p. 647). The authors cited a number of factors that contributed to visitor satisfaction, including the diving experience and particular dive sites, the most significant factor being the closeness of approaches by the whales, total number of whales seen and total time spent with whales.

Until research addresses the ecological and human dimensions of whale watching more thoroughly, it is likely that the resource and the recreational experience will be degraded (Clark, Simmonds, \& Williams-Grey 2007; Higham \& Lusseau 2007). Long-term strategic planning would help to mitigate the impact of tourism on targeted animals and ensure a responsible and sustainable approach in appreciating cetaceans and their environment (Highamet al. 2008). 


\section{Challenges in the Management of Whalewatching as Eco-Tourism}

There is little doubt that whale watching can be considered an ecotourism activity, but it is precariously balanced when one considers the requisite requirements of ensuring that this activity fully complies with sustainable practices and given its alignment to alternative tourism and ecotourism (Wearing \& Neil, 2009), it should also provide a mechanism to improve the plight of animals that are central to its function. So while whale watching provides the opportunity to demonstrate the potential of ecotourism as sustainable development, and at the same time honoring the principles of conservation it is essential that we see this in practice.

This potential can be realised as Parsons et al. found, where the value of the non-consumptive utilisation of cetaceans (i.e. whale-watching) to rural, coastal communities in West Scotland was three times greater than the value of the consumptive utilisation of cetaceans (i.e. commercial whaling) for rural, coastal communities in Norway.This study demonstrates that the sustainable use cetaceans in Scotland can provide notable financial benefits, while at the same time contributing to the resource upon which this activity is based (2003, p. 397).Whales and dolphins are Scotland's number one wildlife attraction.With $11,770 \mathrm{~km}$ of coastline, the potential for the Scottish industry is huge.In rural areas it can provide as much as $12 \%$ of local income (Woods-Ballard et al. 2003, p. 40).

We would suggest that the consumptive process of ecotourism and the global commodification of animals makes the argument for developing whale watching pervasive with consumerism 'commodifying almost all aspects of social life' (Macnaghten\&Urry 1998, p. 26). However, the use of nature is highly contested. Whale watching might provide a sustainable economic incentive to pursue this activity, while at the same time building political capital upon the world stage if we can find guidelines that ensure the rights of the whale are respected.

Ecotourism provides a vehicle for economic development within the context of conservation.As Patrick Ramage, Whale Program Director of the IFWA, aptly puts it, 'At a time when the global economy, our planet's great whales and international whale conservation measures are all under threat, it is encouraging to see coastal communities the world over continuing to reap increasing benefits from this rapidly developing form of ecotourism’ (O’Connor et. al. 2009, p. 9). 
The rapid growth in the demand for tourist interactions with cetaceans in the wild constitutes a challenge to management, as short-term animal behaviour changes can have long-term biological consequences for individual animals and populations. Whale watching management therefore encompasses macro, meso and micro dialogues that contribute to the way we view whales on the global and local levels.

Whale watching management derives from this context and at the same time contributes the evolution of thoughts regarding the use and protection of whales.In an effort to improve the current shortcomings in the long-term management of whale watching activities, Higham et al. (2008) suggest the use of an integrated and adaptive management model, based largely upon the delineation and monitoring of limits of acceptable change (LAC).Likewise, Curtin suggests that LAC guide the development of sustainable whale watching within the larger context of nature-based tourism and the preservation of biodiversity (2003, p. 173).

Developing a global code of ethics might go a long way in regulating the consumption of nature, but this is complicated by different cultural values.Adopting the developmental model of ecotourism, with its built-in code of ethics, would provide a vehicle to pursue whale watching for sustainable economic gain, while at the same time adhering to the general principles of conservation.Ecotourism provides a business model that would provide an avenue for economic growth and the development of political capital.It would allow whale watching to be repositioned as an economic activity, rather than as a contested cultural activity.

We suggest in concluding that by scrutinising the intersection of globalised and localised environmentalism as in Lajes do Pico in the Azores (Portugal) at the historical juncture when whale watching superseded whale hunting in this village, Neves-Graça sheds light on cultural valuations and how they evolve through interaction.The author explains how localised environmentalism (including the ecological knowledges and practices of local inhabitants) was reproduced, learned, and transformed within the context of globalised environmental concerns (2006, p. 19).Conversely, globalised, macro-cultural discourses have an influence upon local actors, interweaving local and distant dialogues into a mutually constituted, albeit contested, narrative. 
Promoting whale watching through the ecological and economic developmental model of ecotourism would act upon the local and global discourses on conservation.The intersection of these discourses marks the cutting edge of this narrative and point to the future.

\section{Conclusion}

This review of the literature has highlighted a number of factors which impact on the development of whale watching as a sustainable activity in the context of eco-tourism. These can be categorised as factors related to tourists and the practices of the tourist industry; factors relating to the cetaceans themselves, their biology and behaviours; and factors relating to the environment. Each of these factors may be underpinned by cross-cutting cultural, scientific and economic themes. This complexity in the literature is further compounded by conflicts in study findings, for example in the scientific literature on cetacean behaviours in the context of tourist activities. Although it may be possible to propose whale watching as an alternative to the practices of commercial whaling and there is considerable optimism that this ecotourism activity can indeed live up to its promises of sustainable practice, there is no simple approach which can be adopted worldwide. This review suggests the need for more research into whale-watching as eco-tourism, with an emphasis on the differences in local context that may affect the outcomes of the research.

\section{References}

AFP 2009, June 24, Whales worth more alive than dead, says new report, Sydney Morning Herald, Online. http://news.smh.com.au/breaking-news-world/whales-worth-morealive-than-dead-says-new-report-20090624-cvjd.html, retrieved on April 5, 2010.

Amante-Helweg, V. 1996, 'Ecotourist's beliefs and knowledge about dolphins and the development of cetacean ecotourism',Aquatic Mammals,vol. 22, no. 2, pp. 131-140.

Anderson, G.R.V., Forbes, M.A. \&Pirzl, R.M. 1996, 'A national overview of the development of whale watching in Australia', in Cogan, K., Presser, S. \&Jeffery, A. (eds),Encounters with Whales - 1995 Proceedings,Australian Nature Conservation Agency, Canberra, pp. 5-16.

Blewitt, M. 2008, 'Dolphin-human interactions in Australian waters',Australian Zoologist,vol. 34, (Special Issue), pp. 197-210.

Boo, E. 1990,Ecotourism: The Potentials and Pitfalls (vols 1\&2), WorldWide Fund for Nature, Washington, DC.

Clark, J., Simmonds, M., \& Williams-Grey, V. 2007, ‘Close encounters: Whale watching in the UK',Biologist, vol.54, no. 3, pp. 134-141.

Cloke, P., \& Perkins, H.C. 2005, 'Cetacean performance and tourism in Kaikoura, New Zealand', Environment and Planning D: Society and Space, vol.23, no. 6, pp. 903924.http://dx.doi.org/10.1068/d57j 
Cole, S. 2007, 'Implementing and evaluating a code of conduct for visitors', Tourism Management, vol. 28, no. 2,pp. 443451.http://dx.doi.org/10.1016/j.tourman.2006.03.010

Corkeron, P.J. 1996, 'Research priorities for whale watching in Australia: a scientist's viewpoint', in: Cogan, K. Presser, S. \& Jeffery, A. (eds),Encounters with Whales - 1995 Proceedings, Australian Nature Conservation Agency, Canberra, pp. 123-135.

Corkeron, P. J. 2004, 'Whale watching, iconography and marine conservation',Conservation Biology,vol. 18, no. 3, pp. 847-849.http://dx.doi.org/10.1111/j.1523-1739.2004.00255.x

Corkeron, P. 2006, ‘How shall we watch whales?’ in Lavigne, D. (ed), Gaining Ground: In Pursuit of Ecological Sustainability, International Fund for Animal Welfare,Guelph, Ontario,pp. 161-170.

Cunningham, P. A. 2007,'Baselining sustainable practices in Ogasawara’,RikkyoDaigakuKankogakubu Kiyo, vol.9, pp. 44-49.

Curtin, S. 2003, 'Whale-watching in Kaikoura: Sustainable destination development?', Journal of Ecotourism, vol. 2, no. 3, pp. 173-195. http://dx.doi.org/10.1080/14724040308668143

Denardo, C., Dougherty, M., Hastie, G., Leaper, R., Wilson, B. \& Thompson, P.M. 2001, ‘A new technique to measure spatial relationships within groups of free-ranging coastal cetaceans',Journal of Applied Ecology, vol. 38, pp. 888-895.

Duffus, D.A. \& Deaden, P. 1993, 'Recreational use, valuation and management of Killer Whales (Orcinus orca) on Canada's Pacific coast',Environmental Conservation, vol. 20, no. 2, pp. 149-156.http://dx.doi.org/10.1017/S0376892900037656

Ecotourism Australia 2010, Home page.http://www.ecotourism.gr.jp/, retrieved on June 5, 2010.

Einarsson, N. 2009, 'From good to eat to good to watch: Whale watching, adaptation and change in Icelandic fishing communities',Polar Research,vol. 28, no. 1, pp. 129138.http://dx.doi.org/10.1111/j.1751-8369.2008.00092.x

Foxlee, J. 2001, 'Whale watching at Hervey Bay’,Parks and Leisure Australiavol. 4, no. 3, pp. $17-18$.

Gillespie, A. 2003, 'Legitimating a whale ethic’,Environmental Ethics,vol.25, no. 4, pp. 395410.http://dx.doi.org/10.5840/enviroethics20032545

Greenpeace (2010).Iceland whaling.http://archive.greenpeace.org/whales/iceland/WhaleWatching.htm, retrieved on April 26, 2010.

Higham, J. E. S., \&Lusseau, D. (2007).Urgent need for empirical research into whaling and whale watching.Conservation Biology 21(2), 554-558.http://dx.doi.org/10.1111/j.15231739.2006.00580.x

Higham, J. E. S., \&Lusseau, D. 2008, 'Slaughtering the goose that lays the golden egg: Are whaling and whale-watching mutually exclusive?'Current Issues in Tourism, vol. 11, no. 1, pp. 63-74.http://dx.doi.org/10.2167/cit335.0

Higham, J.E.S., Bejder, L., \&Lusseau, D. 2008,'An integrated and adaptivemanagement model to address the long-term sustainability of tourist interactions with cetaceans', Environmental Conservation,vol. 35, no. 4, pp. 294302.http://dx.doi.org/10.1017/S0376892908005249

Hobson, K., \& S. Essex 2001, 'Sustainable tourism: A view from accommodation businesses’, The Service Industries Journal, vol. 21, no. 4, pp. 133146.http://dx.doi.org/10.1080/714005050

Hoyt, E. 1996, 'Whale watching: a global overview of the industry's rapid growth and some implications and suggestions for Australia’, in Cogan, K., Presser, S. \&Jeffery, A. 
(eds),Encounters with Whales - 1995 Proceedings, Australia: Australian Nature Conservation Agency, Canberra, pp. 31-36.

Hoyt, E. 2005, 'Sustainable ecotourism on Atlantic islands, with special reference to whale watching, marine protected areas and sanctuaries for cetaceans',Biology and Environment, vol. 105, no. 3, pp. 141-154. http://dx.doi.org/10.3318/BIOE.2005.105.3.141

International Foundation for Animal Welfare (IFAW) 2010, 'The Booming Whale Watching Industry’, http://www.mywhaleweb.com/?page_id=289, retrieved April 6, 2010.

Japan Ecotourism Society 2010, Home page. http://www.ecotourism.gr.jp/, retrieved June 5, 2010.

Jensen, F. H., Bejder, L., Wahlberg, M., Soto, N. A., Johnson, M. \& Madsen, P. T. 2009, 'Vessel noise effects on delphinid communication',Marine Ecology Progress Series,vol. 395, pp. 161-175.http://dx.doi.org/10.3354/meps08204

King, D.A. \& Stewart, W.P. 1996, 'Ecotourism and commodification: Protecting people and places', Biodiversity and Conservation, vol.5, no. 3. Pp. 293-305. http://dx.doi.org/10.1007/BF00051775

Kirk, D. 1996,Environmental Management for Hotels, Butterworth, Oxford.

Kuo, H., Chen, C. C., \&McAleer, M. 2009,Estimating the Impact of Whaling on Global Whale Watching, Available at SSRN: http://ssrn.com/abstract=1442444http://dx.doi.org/10.2139/ssrn.1442444

Lawrence, T. B. \& Phillips, N. 2004,'From Moby Dick to Free Willy: Macro-cultural discourse and institutional entrepreneurship in emerging institutional fields', Organization,vol. 11, no. 5, pp. 689-711.http://dx.doi.org/10.1177/1350508404046457

Leaper, R. \& Gordon, J. 2001, 'Application of photogrammetric methods for locating and tracking cetacean movements at sea’, Journal of Cetacean Research Management, vol. 3, no. 2, pp. 131-141.

Lien, J. 2001, The Conservation Basis for the Regulation of Whale Watching in Canada by the Department of Fisheries and Oceans: A Precautionary Approach, Canadian Technical Report of Fisheries and Aquatic Sciences, No. 2363.

Lück, M. 2003,'Education on marine mammal tours as agent for conservation - But do tourists want to be educated?'Ocean and Coastal Management, vol. 46, nos. 9-10, pp. 943-956.http://dx.doi.org/10.1016/S0964-5691(03)00071-1

Lusseau, D. 2004,'The hidden cost of tourism: Detecting long-term effects of tourism using behavioral information',Ecology and Society, vol. 9, no. 1, http://www.ecologyandsociety.org/vol9/iss1/art2.

Lusseau, D., Bain, D. E., Williams, R., \& Smith, J. C. 2009, 'Vessel traffic disrupts the foraging behavior of southern resident killer whales Orcinus orca',Endangered Species Research,vol. 6, no. 3, pp. 211-221.http://dx.doi.org/10.3354/esr00154

Macnaghten, P.\&Urry, J. 1998,Contested natures, Sage Publications, London.

Muloin, S. 1998, 'Wildlife tourism: the psychological benefits of whale watching', Pacific Tourism Review,vol. 2, pp. 199-213.

Neil, D.T. \& Breeze, L. 1998,'Topics of interest to participants in human-marine mammal interactions: a preliminary report', in Roams, M.B.\& Neil, D.T. (eds),Dolphin and Whale Research at Tangalooma1989-1998, Massey University, Auckland, pp. 167-171.

Neves-Graça, K. (2006, 'Politics of environmentalism and ecological knowledge at the intersection of local and global processes', Journal of Ecological Anthropology,vol. 10, pp. 19-32.http://dx.doi.org/10.5038/2162-4593.10.1.2

Noren, D. P., Johnson, A. H., Rehder, D.\& Larson, A. 2009, 'Close approaches by vessels elicit surface active behaviors by southern resident killer whales’,Endangered Species Research,vol. 8, no. 3, pp. 179-192.http://dx.doi.org/10.3354/esr00205 
O’Connor, S., Campbell, R., Cortez, H. \& Knowles, T. 2009, Whale Watching Worldwide: tourism numbers, expenditures and expanding economic benefits, a special report from the International Fund for Animal Welfare. Yarmouth MA, USA, prepared by Economists at Large.

Orams, M. B. 2001, 'From whale hunting to whale watching in Tonga: A sustainable future?' ,Journal of Sustainable Tourism, vol. 9, no. 2, pp. 128146.http://dx.doi.org/10.1080/09669580108667394

Orams, M.B. 2000.'Tourists getting close to whales, is it what whale-watching is all about?',Tourism Management,vol. 21, no. 6, pp. 561569.http://dx.doi.org/10.1016/S0261-5177(00)00006-6

Orams, M.B. 1999,Marine tourism: Development, impacts and management, Routledge, London.

Parsons, E. C. M. \&Draheim, M. 2009, 'A reason not to support whaling - a tourism impact case study from the Dominican Republic’, Current Issues in Tourism, vol. 12, no. 4, pp. 397-403.http://dx.doi.org/10.1080/13683500902730460

Parsons, E. C. M.,Lück, M. \& Lewandowski, J. K. 2006, 'Recent advances in whalewatching research: 2005-2006',Tourism in Marine Environments, vol.3, no. 2, pp. 179189.http://dx.doi.org/10.3727/154427306779435247

Parsons, E.C.M., Warburton, C.A., Woods-Ballard, A., Hughes, A.\& Johnston, P. 2003, 'The value of conserving whales: The impacts of cetacean-related tourism on the economy of rural West Scotland',Aquatic Conservation: Marine and Freshwater Ecosystems,vol. 13, no. 5, pp. 397-415.http://dx.doi.org/10.1002/aqc.582

Ryan, C., \&Saward, J. 2004, 'The zoo as ecotourism attraction - Visitor reactions, perceptions and management implications: The case of Hamilton Zoo, New Zealand',Journal of Sustainable Tourism, vol. 12, no. 3, pp. 245266.http://dx.doi.org/10.1080/09669580408667236

Scarpaci, C., Parsons, E. C. M. \&Lück, M. 2008, 'Recent advances in whale-watching research: 2006-2007’,Tourism in Marine Environments,vol. 5, no. 1, pp. 5566.http://dx.doi.org/10.3727/154427308785855288

Simmonds, M. P. \& Isaac, S. J. 2007,'The impacts of climate change on marine mammals: Early signs of significant problems’, $O R Y X$, vol. 41, no. 1, pp. 1926.http://dx.doi.org/10.1017/S0030605307001524

Sousa-Lima, R. S., \& Clark, C. W. 2008,'Modeling the effect of boat traffic on the fluctuation of humpback whale singing activity in the Abrolhos National Marine Park, Brazil',Canadian Acoustics - AcoustiqueCanadienne,vol. 36, no. 1, pp. 174-181.

Stamation, K. 2008, 'Understanding human-whale interactions: A multidisciplinary approach',Australian Zoologist, vol. 34, (Special Issue.), pp. 211-224.

Stamation, K. A., Croft, D. B., Shaughnessy, P. D., Waples, K. A. \& Briggs, S. V. 2007, 'Educational and conservation value of whale watching',Tourism in Marine Environments, vol. 4, no. 1, pp. 41-55.http://dx.doi.org/10.3727/154427307784835660

Stamation, K. A., Croft, D. B., Shaughnessy, P. D., Waples, K. A.\& Briggs, S. V. 2010, 'Behavioral responses of humpback whales (Megapteranovaeangliae) to whalewatching vessels on the southeastern coast of Australia',Marine Mammal Science,vol. 26, no. 1, pp. 98-122.http://dx.doi.org/10.1111/j.1748-7692.2009.00320.x

Tisdell, C., \& Wilson, C. 2005, 'Perceived impacts of ecotourism on environmental learning and conservation: Turtle watching as a case study', Environment, Development and Sustainability, vol. 7, no. 3, pp. 291-302.http://dx.doi.org/10.1007/s10668-004-7619-6

Tosi, C. H., \& Ferreira, R. G. 2009, 'Behavior of estuarine dolphin, Sotaliaguianensis (Cetacea, Delphinidae), in controlled boat traffic situation at southern coast of Rio 
Grande do Norte, Brazil', Biodiversity and Conservation,vol. 18, no. 1, pp. 6778.http://dx.doi.org/10.1007/s10531-008-9435-z

Valentine, P.S., Birtles, A., Curnock, M., Arnold, P., Dunstan, A. 2004, ‘Getting closer to whales - Passenger expectations and experiences, and the management of swim with dwarf minke whale interactions in the Great Barrier Reef', Tourism Management,vol. 25, no. 6, pp. 647-655.http://dx.doi.org/10.1016/j.tourman.2003.09.001

Vieira, N. \&Brito, C. 2009, 'Past and recent sperm whales sightings in the Azores based on catches and whale watching information',Journal of the Marine Biological Association of the United Kingdom,vol. 89, no. 5, pp. 10671070.http://dx.doi.org/10.1017/S0025315409000873

Wearing, S.L., Buchmann, A. \&Jobberns, C. 2011,'Free Willy: the whale-watching legacy', Worldwide Hospitality and Tourism Themes, vol. 3, no. 2, pp. 127-140.

Wearing S. L. \& Neil, J. 2009,Ecotourism: impacts, potential and possibilities, $2^{\text {nd }}$ ed., Butterworth-Heinemann, Oxford.

Weinrich, M.T.\&Corbelli, C. 2009, 'Does whale watching in Southern New England impact humpback whale (Megapteranovaeangliae) calf production or calf survival?’,Biological Conservation,vol. 142, pp. 2931-2940.http://dx.doi.org/10.1016/j.biocon.2009.07.018

Whale and Dolphin Watch Australia 2010, Home page,http://www.whaleanddolphinwatchaustralia.com.au/research.php, retrieved April 8, 2010.

Wight, P. 1993, 'Ecotourism: Ethics or Eco -Sell',Journal of Travel Research, vol. 31, no. 3, pp. 3-9.http://dx.doi.org/10.1177/004728759303100301

Wight, P. 1994,'Environmentally responsible marketing of tourism', in Cater, E.\& Lowman, G. (eds),Ecotoursim: A sustainable option? Wiley, New York,pp.39-55.

Wiley, D.N., Moller, J.C. \& Carlson, C. 2004, Compliance with voluntary speed guidelines by the commercial whale watching industry in and around the Stellwagen Bank National Marine Sanctuary. Paper SC/56/WW9 presented to the IWC Scientific Committee, Sorrento, Italy. 9pp.

Williams, R., Bain, D.E., Smith, J. C. \&Lusseau, D. 2009,'Effects of vessel on behaviour patterns of individual southern resident killer whales orcinus orca',Endangered Species Research, vol. 6, no. 3, pp. 199-209.http://dx.doi.org/10.3354/esr00150

Williams, R. \&Crosbie, K. 2007, 'Antarctic whales and Antarctic tourism’,Tourism in Marine Environments,vol. 4, nos. 2-3, pp. 195202.http://dx.doi.org/10.3727/154427307784772039

Woods-Ballard, A.J., Parsons, E.C.M., Hughes, A.J., Velander, K.A., Ladle, R.J. \& Warburton, C. A. 2003, 'The sustainability of whale-watching in Scotland', Journal of Sustainable Tourism,vol. 11, no. 1, pp. 4055.http://dx.doi.org/10.1080/09669580308667192

Zeppel, H. \&Muloin, S. 2008, 'Conservation benefits of interpretation on marine wildlife tours',Human Dimensions of Wildlife: An International Journal, vol. 13, no. 4, pp. 280-294.http://dx.doi.org/10.1080/10871200802187105 